Review

\title{
Quadruple Screening in the Age of Cell-Free DNA: What are We Losing?
}

Alison Schmidt ${ }^{1,}{ }^{*}$, Anthony Shanks ${ }^{2, *}$

1. Indiana University School of Medicine, Indianapolis, IN, USA; E-Mail: alimschm@iu.edu

2. Department of Obstetrics and Gynecology, Indiana University School of Medicine, Indianapolis IN, USA; E-Mail: ashanks@iupui.edu

* Correspondence: Alison Schmidt and Anthony Shanks; E-Mails: alimschm@iu.edu; ashanks@iupui.edu

Academic Editors: Diane B. Paul and Ilana Löwy

Special Issue: $\underline{\text { Policy Issues in Prenatal and Neonatal Testing, Counseling, and Decision-Making }}$

OBM Genetics

2021, volume 5 , issue 3

doi:10.21926/obm.genet.2103138
Received: June 16, 2021

Accepted: September 17, 2021

Published: September 27, 2021

\begin{abstract}
Cell-free DNA has emerged as the most reliable, non-invasive prenatal screening tool for fetal aneuploidies. It has come to replace the previously widely used quadruple screen offered in the second trimester of pregnancy. This change comes with improved detection for aneuploidy but also presents potential gaps in prenatal diagnosis including detection of open fetal defects and emerging data on prediction of adverse pregnancy outcomes. This review article provides a historical summary of the quadruple marker screen and evaluates the intersection of this screen with cell-free DNA. Furthermore, it discusses points to consider as providers trend toward cell-free DNA testing alone and reviews potential options to remedy any disparities.
\end{abstract}

\section{Keywords}

Quadruple screen; non-invasive prenatal testing (NIPT); cell-free DNA; prenatal testing

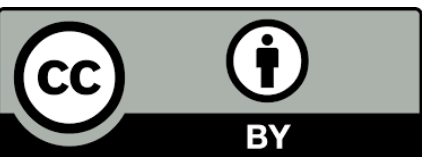

(C) 2021 by the author. This is an open access article distributed under the conditions of the Creative Commons by Attribution License, which permits unrestricted use, distribution, and reproduction in any medium or format, provided the original work is correctly cited. 


\section{Introduction}

The American College of Obstetrics and Gynecology (ACOG) recommends that all pregnancies be screened for fetal aneuploidy, particularly those of higher risk, including advanced maternal age and prior family history [1]. The quadruple ("quad") screen is one non-invasive tool available for pregnancy screening [1]. The test is conducted in the second trimester of pregnancy and uses four markers: alpha-fetoprotein (AFP), human chorionic gonadotropin (hCG), unconjugated estriol, and dimeric inhibin-A [1]. The screen is used to help determine the risk of fetal aneuploidy and subsequently guide pregnancy management. The quadruple screen has become ubiquitous in its use across obstetrics providers, with continued discovery of additional applications.

Recently, technology that utilizes circulating fetal DNA in maternal serum, termed cell-free DNA testing, has increasingly become the gold standard in prenatal aneuploidy screening, due to its improved sensitivity and specificity for these conditions [1]. By its nature as a genetic test, cell-free DNA is only able to evaluate genetic risks, thereby leaving potential gaps in prenatal testing that the quad screen had previously been able to address.

\section{A History of the Quadruple Screen for Aneuploidy Screening}

The development of the quadruple screen for aneuploidy risk, particularly Trisomy 21, spanned decades, as understanding of maternal serum markers improved over time [Figure 1]. Trisomy 21 ("Down syndrome") is a common fetal aneuploidy syndrome, characterized by such physical abnormalities as hypotonia, a flat nasal bridge and upward slanting palpebral fissures [2]. Children with Trisomy 21 also have an increased risk of cognitive impairment, hearing loss, congenital heart defects, and other lifelong medical conditions [2]. As early as the 1930s, the risk of fetal aneuploidies was known to increase with maternal age, which we now understand to be secondary to increased meiotic nondisjunction events resulting in additional chromosome 21 material [3]. Prior to the 1980s, advanced maternal age was the only screening modality used to recommend further diagnostic testing (amniocentesis at the time) for trisomy 21 [4].

However, in 1984, a relationship between AFP and trisomy 21 was presented by Cuckle et al [5]. Pregnancies affected by this aneuploidy were shown to produce less AFP, a protein produced by the fetal liver, leading to reduced maternal serum levels [5]. Refinement of the AFP screening strategy accounting for maternal age and ultrasound-confirmed dating was proposed in 1987, with sensitivity for trisomy 21 reaching 40\% [4].

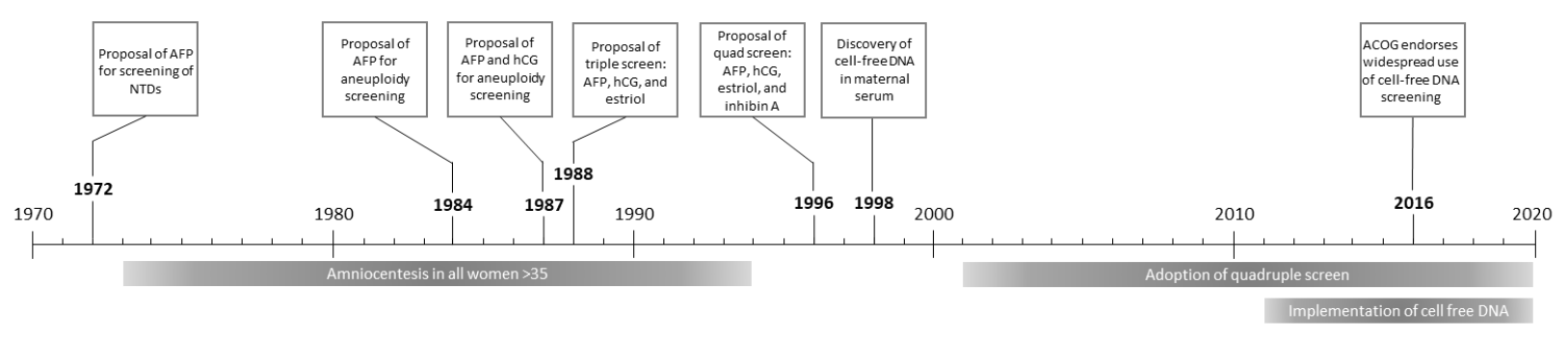

Figure $1 \mathrm{~A}$ timeline of the development of the quadruple screen.

Within the same year, the addition of hCG to the fetal chromosomal abnormality algorithm was proposed [6]. By this time, it had been known for decades that abnormal levels of hCG were associated with adverse pregnancy outcomes, namely spontaneous abortions [7]. It was also 
understood at the time that a majority of spontaneous abortions are due to chromosomal abnormalities [6]. In the case of Trisomy 21, hCG levels were demonstrated to be elevated compared to unaffected pregnancies [6]. By combining AFP and hCG, the detection rate for any chromosomal abnormalities (including trisomy $21,18,13$, and monosomy $\mathrm{X}$ ) was improved to up to $75 \%$ of cases from $20 \%$ with AFP alone in their cohort [6].

The earliest proposal of what is now referred to as the triple screen included AFP, hCG and unconjugated estriol (the primary estrogen produced by the placenta) and was introduced in 1988. Wald et al. identified that the combination of the three markers, in addition to maternal age was able to improve detection rate and reduce false positives in the screening of trisomy 21 [8]. Further studies confirmed that low estriol, in combination with low AFP, high hCG and advanced maternal age, provided a positive predictive value $50-300 \%$ higher than simply AFP alone in the detection of trisomy 21 [9].

By 1994, the standard of care was still offering amniocenteses to all pregnant women over the age of 35 [10], as 1 in 294 pregnancies are affected by Trisomy 21 at this age [1]. Although invasive diagnostic testing, including amniocentesis and chorionic villus sampling (CVS), is generally regarded as safe, it carries risks, the most significant being the risk of pregnancy loss [11]. The use of maternal aneuploidy screening is an attractive alternative to avoid unnecessary invasive diagnostic testing. In a large study of over 5000 women, Haddow et al. demonstrated that the rates of invasive diagnostic procedures could be reduced through use of the triple screen. In this study, researchers found that if amniocentesis were only offered in pregnancies with a greater than 1 in 200 chance of being affected by trisomy 21 per the triple screen, the number of unnecessary procedures would dramatically decrease, while maintaining a detection rate of $89 \%$ of the cases of trisomy 21 [10].

In 1996, Wald et al. introduced the concept of the quadruple screen, adding inhibin-A to the established triple screen protocol. Given that hCG levels are increased in the setting of trisomy 21 , it was hypothesized that elevations of another placentally-produced hormone, inhibin-A, may further improve the sensitivity and specificity of the screening test for Trisomy 21 [12]. With further optimization by adjusting for ultrasound-confirmed gestational age and maternal weight, the quad screen improved detection rates to $79 \%{ }^{1}$ [12].

Until the early 2000s, most of the research focused on the ability to detect trisomy 21, with little data regarding other fetal aneuploidies. The First and Second Trimester Evaluation of Risk (FASTER) trial was a multicentered study aimed at comparing the available screening methods for Trisomy 21, which included the second trimester quadruple screen serum markers, as well as first trimester markers (PAPP-A, free beta-hCG and nuchal translucency) [13]. It also evaluated the success of these screening modalities for chromosomal abnormalities other than trisomy 21 [14]. In a cohort of around 35,000 women who received quad screening during the second trimester of their pregnancy, the detection rate of pregnancies complicated by trisomy 18 , trisomy 13 or monosomy $X$ was $69 \%$, with a false positive rate of $8.9 \%$ [14].

As the data behind the quad screen increased, so too did adoption rates by obstetricians. By 2004, second trimester quadruple screening was adopted by around half of American obstetricians [15]. By $2008,86 \%$ of American general obstetricians offered this screen [16]. Another study found a $10-$ fold increase in the use of the quad screen by maternal-fetal medicine specialists, increasing from

\footnotetext{
${ }^{1}$ Of note, some researchers have proposed a "penta" screen, which aims to improve the quad screen by incorporating hyperglycosylated hCG [1]. Clinical studies using this screen are still limited [1].
} 
$8.5 \%$ in 2001 to $85.6 \%$ in 2007 [17]. The same study also identified a predicted $20 \%$ decrease in the number of invasive procedures during this time [17].

\section{Enter Cell-Free DNA}

Non-invasive prenatal testing (NIPT) in modern times has largely come to mean the use of circulating cell-free DNA for prenatal screening of chromosomal abnormalities. Early on, researchers were primarily interested in the presence of whole fetal cells in maternal DNA, spurring the National Institutes of Health Fetal Cell Study (NIFTY) [18]. Initial data was promising, with false positive rates in aneuploidy screening lower than the $5 \%$ rate observed in serum analyte screening at the time [19]. However, isolation of sufficient free cells for testing proved to be challenging, particularly in pregnancies with cytogenetically normal fetuses [20]. While optimization efforts were underway, Lo et al. identified that cell-free DNA was also present in the maternal serum, opening a new line of research [21].

This field of study rapidly progressed, as it was determined that fetal DNA was present in high concentrations, with detectable levels as early as the $7^{\text {th }}$ week of pregnancy [22]. Early on, the benefit was believed to be limited to determination of sex, sex-linked disorders, and Rh status, given the need for a fetal specific marker (ex. Y chromosome) to distinguish from background maternal DNA [23, 24]. However, advancements in alternative fetal markers including epigenetic markers [25, $26]$ and use of highly polymorphic single nucleotide variants within regions of interest $[27,28]$ has allowed for the technology to detect common aneuploidies.

A 2017 meta-analysis by Gil et al. estimates that cell-free DNA has a detection rate for trisomy 21 of $99.7 \%$ and a false positive rate of $0.04 \%$ [29], far superior to second trimester quad screening, which estimates a detection rate of $81 \%$ of pregnancies affected by trisomy 21 and a false positive rate of $5 \%$ [14]. The meta-analysis also found weighted detection rates for trisomy 18 , trisomy 13 , and monosomy $X$ to be $98 \%, 99 \%$, and $96 \%$, respectively [29]. Aneuploidy screening through cellfree DNA is now endorsed as the most sensitive and specific screening test for this purpose by ACOG and the Society for Maternal-Fetal Medicine (SMFM) [1]. These societies recommend all patients be offered aneuploidy screening, regardless of maternal age [1]. Cell-free DNA may also have future benefits in prenatal diagnosis of single gene disorders, as the technology develops, further setting its capabilities apart from the serum analyte screens [30].

\section{What Cell-Free DNA misses}

There is no debate that cell-free DNA is superior to the quadruple screen in its ability to screen for fetal aneuploidy [29]. However, cell-free DNA has distinct disadvantages to the quad screen. The first is in the detection of open fetal defects, including neural tube defects (NTDs) and abdominal wall defects. The second stems from the relative newness of this technology. Components of the quadruple screen have been studied for decades, with continued discoveries of novel and alternative applications.

\subsection{AFP and Open Fetal Defects}

Well before the discovery of AFP as a screening tool for trisomy 21, it was widely used to identify pregnancies affected by neural tube defects (NTDs) or abdominal wall defects. AFP, first identified 
in the 1950s [31], is elevated in maternal serum in pregnancies affected by these open fetal defects. In such pregnancies, it is believed that these lesions result in the lack of a complete barrier between fetal serum or cerebrospinal fluid and amniotic fluid [32]. This allows the protein to leak into the amniotic fluid, subsequently crossing over into maternal serum at elevated concentrations [32]. This relationship was first discovered by Brock et al. in 1972 [33], and its use as a screening tool was further characterized in 1977 by a U.K. collaborative study of over 18,000 pregnancies [34]. One meta-analysis finds that the use of noninvasive maternal serum AFP screening is $75.1 \%$ sensitive and 97.7\% specific for the detection of neural tube defects [35]. Similarly, detection rate of abdominal wall defects resulting in herniation of abdominal contents both with an overlying membrane (omphalocele) and without (gastroschisis) using AFP screening has been demonstrated to be $78 \%$ and $>99 \%$ respectively, when using a cut off of $\geq 2.0$ multiples of the median (MoM) [36].

Early in the implementation of cell-free DNA, the 2015 committee opinion published by ACOG recommended providers also offer AFP testing to identify pregnancies at risk for open neural tube defects [37]. Further studies have since demonstrated that routine second trimester ultrasonography of fetal anatomy has a $100 \%$ sensitivity and specificity in the diagnosis of both neural tube and ventral wall defects using an anatomy ultrasound scan [38]. This practice is now recommended by ACOG [39] and has been demonstrated to be more effective than AFP screening alone in detecting neural tube defects [40].

It is worth noting, however, that this combination of cell-free DNA with US testing is not without its own limitations. ACOG currently endorses the optimum gestational age of obtaining the anatomy scan to be 18-22 weeks in the absence of earlier indications [39], in part due to data that suggests earlier scans may be less effective in detecting neural tube defects [41]. Historically, abnormalities in maternal AFP levels early in pregnancy indicated the need for an earlier anatomic scan, given the associated increased risk for anatomical defects. Therefore, moving away from quad screening or AFP testing entirely may result in later diagnosis of these complications.

\subsection{Other Quadruple Screen Applications}

In addition to chromosomal abnormalities and open fetal defects, there is a growing body of evidence that abnormal results from multiple quadruple screen serum markers may indicate a greater risk for adverse pregnancy outcomes, including placental abruption, intrauterine growth restriction (IUGR), fetal death and preterm birth $[42,43]$. The link between these pregnancy outcomes and abnormalities in these markers likely stems from placental malfunction [42]. Data from the FASTER trial demonstrate a significant association between elevations in three serum markers (specifically hCG, AFP, and inhibin A) with preterm birth (OR 5.51 [95\% Cl: 2.23-13.62]), preeclampsia (OR 7.04 [95\% Cl 3.90-12.73]) and fetal loss $\leq 24$ weeks (OR 16.34 [95\% Cl: 7.56-35.33]), among others [43]. However, the sensitivity of this screen for these conditions is low (15.95\%, $11.74 \%$, and $24.74 \%$, respectively) which limits the predictive value in the general population [43]. A Cochrane review of the use of serum markers as a screen for small for gestational age neonates also found that quad screening alone may not be a sufficient screen [44].

Despite this, information from the quad screen could be valuable in directing further testing or antenatal surveillance. Abnormal levels of both AFP and Inhibin-A have been associated with an increased risk of stillbirth [45]. One study found that AFP levels greater than 2.5 MoM demonstrated a relative risk of spontaneous abortion of 12.5 [95\% Cl: 9.7-16.1] compared to AFP levels of 0.75- 
1.24 MoM, but this association did not persist when adjusted for low birth weight [46]. However, rates of stillbirth with Inhibin-A values greater than 2.0 MoM on second trimester serum analyte screening are as high as 9.4 per 1,000, despite adjusting for low birth weight. This has prompted a recent update to the committee opinion published by ACOG and SMFM on the topic recommends that providers consider weekly fetal surveillance starting at 36 weeks gestation for these pregnancies [45].

Additionally, the 2008 recommendations from the Society of Obstetricians and Gynaecologists of Canada (SOCG) recommend that an unexplained increased AFP in the setting of placenta previa warrants additional imaging and altered delivery planning due to the high association with an invasive placental pathology (ex. placenta accreta) [47]. Yet another practical example involves a case study, wherein a team identified a pregnancy with IUGR and used the quad screening to determine the likely etiology to be related to placental pathology [48]. The clinicians used this information to initiate prophylactic enoxaparin and aspirin in an attempt to normalize umbilical artery blood flow prior to delivery [48].

While studies of the predictive value of quadruple screen markers are ongoing, it is worth noting that there are additional investigational studies assessing the correlation between an abnormal level of cell free DNA in maternal serum and adverse pregnancy outcomes. A recent systematic review of retrospective cohort studies by Scheffer et al. finds that low levels of circulating fetal DNA in maternal serum is associated with pregnancy complications, including hypertensive diseases of pregnancy, preterm birth, and small for gestational age neonates [49]. The utility of any of these markers as predictors of adverse pregnancy outcomes will require further investigation.

\section{Conclusions}

The development of the quad screen helped to identify pregnancies at the highest risk of body wall defects and fetal aneuploidy, allowing for a reduction in the amount of invasive diagnostic testing. NIPT has since emerged as a more sensitive and specific means of identifying possible fetal aneuploidy. As we move more towards this means of screening, it is important to recognize the potential gaps that this testing alone leaves. The largest of these gaps is the detection of NTDs and abdominal wall defects, making routine second trimester US a critical component of the prenatal testing algorithm. Additionally, there is ongoing investigational research that might suggest a further benefit of serum screens in obtaining additional information about placental function and adverse pregnancy outcomes.

Prenatal screening modalities are rapidly evolving, highlighting the importance of counseling by obstetrics providers. Per ACOG recommendations, all patients should be counseled on the available prenatal aneuploidy screening options, regardless of baseline risk [1]. Cell-free DNA is the superior aneuploidy test with regards to sensitivity and specificity and should be offered to patients starting at 9-10 weeks of pregnancy [1]. Additionally, routine second-trimester ultrasound screening for fetal anomalies should be offered to all pregnant patients, with the optimal screening timing of 18-22 weeks [39]. 


\section{Author Contributions}

A. Schmidt contributed to the concept of the research, conducted the literature review, and wrote the manuscript. A. Shanks contributed to the concept of the study and assisted with manuscript writing.

\section{Competing Interests}

The authors have declared that no competing interests exist.

\section{References}

1. Screening for fetal chromosomal abnormalities [Internet]. Washington, DC: American College of Obstetricians and Gynecologists; 2020 [cited 2021 April 06]. Available from: https://www.acog.org/en/clinical/clinical-guidance/practicebulletin/articles/2020/10/screening-for-fetal-chromosomal-abnormalities.

2. Bull MJ, Committee on Genetics. Health supervision for children with Down syndrome. Pediatrics. 2011; 128: 393-406.

3. Hassold T, Hunt P. To err (meiotically) is human: The genesis of human aneuploidy. Nat Rev Genet. 2001; 2: 280-291.

4. Wald NJ, Cuckle HS. Recent advances in screening for neural tube defects and Down's syndrome. Baillieres Clin Obstet Gynaecol. 1987; 1: 649-676.

5. Cuckle HS, Wald NJ, Lindenbaum RH. Maternal serum alpha-fetoprotein measurement: $A$ screening test for down syndrome. Lancet. 1984; 1: 926-929.

6. Bogart $\mathrm{MH}$, Pandian MR, Jones OW. Abnormal maternal serum chorionic gonadotropin levels in pregnancies with fetal chromosome abnormalities. Prenat Diagn. 1987; 7: 623-630.

7. Brody S, Carlstroem G. Human chorionic gonadotropin in abnormal pregnancy. Serum and urinary findings using various immunoassay techniques. Acta Obstet Gynecol Scand. 1965; 44: 32-44.

8. Wald NJ, Cuckle HS, Densem JW, Nanchahal K, Royston P, Chard T, et al. Maternal serum screening for Down's syndrome in early pregnancy. BMJ. 1988; 297: 883-887.

9. MacDonald ML, Wagner RM, Slotnick RN. Sensitivity and specificity of screening for Down syndrome with alpha-fetoprotein, hCG, unconjugated estriol, and maternal age. Obstet Gynecol. 1991; 77: 63-68.

10. Haddow JE, Palomaki GE, Knight GJ, Cunningham GC, Lustig LS, Boyd PA. Reducing the need for amniocentesis in women 35 years of age or older with serum markers for screening. $\mathrm{N}$ Engl J Med. 1994; 330: 1114-1118.

11. Prenatal diagnostic testing for genetic disorders [Internet]. Washington, DC: American College of Obstetricians and Gynecologists; 2016 [cited 2021 April 06]. Available from: https://www.acog.org/en/clinical/clinical-guidance/practicebulletin/articles/2016/05/prenatal-diagnostic-testing-for-genetic-disorders.

12. Wald NJ, Densem JW, George L, Muttukrishna S, Knight PG. Prenatal screening for Down's syndrome using inhibin-A as a serum marker. Prenat Diagn. 1996; 16: 143-153. 
13. Malone FD, Wald NJ, Canick JA, Ball RH, Nyberg DA, Comstock $\mathrm{CH}$, et al. First- and secondtrimester evaluation of risk (faster) trial: Principal results of the NICHD multicenter down syndrome screening study. Am J Obstet Gynecol. 2003; 189: S56.

14. Breathnach FM, Malone FD, Lambert-Messerlian G, Cuckle HS, Porter TF, Nyberg DA, et al. Firstand second-trimester screening: Detection of aneuploidies other than Down syndrome. Obstet Gynecol. 2007; 110: 651-657.

15. Cleary-Goldman J, Morgan MA, Malone FD, Robinson JN, D'Alton ME, Schulkin J. Screening for Down syndrome: Practice patterns and knowledge of obstetricians and gynecologists. Obstet Gynecol. 2006; 107: 11-17.

16. Driscoll DA, Morgan MA, Schulkin J. Screening for Down syndrome: Changing practice of obstetricians. Am J Obstet Gynecol. 2009; 200: 459.e1-9.

17. Fang YM, Benn P, Campbell W, Bolnick J, Prabulos AM, Egan JF. Down syndrome screening in the United States in 2001 and 2007: A survey of maternal-fetal medicine specialists. Am J Obstet Gynecol. 2009; 201: 97.e1-5.

18. Bianchi DW, Simpson JL, Jackson LG, Evans MI, Elias S, Holzgreve W, et al. Fetal cells in maternal blood: NIFTY clinical trial interim analysis. DM-STAT. NICHD fetal cell study (NIFTY) group. Prenat Diagn. 1999; 19: 994-995.

19. de la Cruz F, Shifrin H, Elias S, Bianchi DW, Jackson L, Evans MI, et al. Low false-positive rate of aneuploidy detection using fetal cells isolated from maternal blood. Fetal Diagn Ther. 1998; 13: 380.

20. Bianchi DW, Williams JM, Sullivan LM, Hanson FW, Klinger KW, Shuber AP. PCR quantitation of fetal cells in maternal blood in normal and aneuploid pregnancies. Am J Hum Genet. 1997; 61: 822-829.

21. Lo YM, Corbetta N, Chamberlain PF, Rai V, Sargent IL, Redman CW, et al. Presence of fetal DNA in maternal plasma and serum. Lancet. 1997; 350: 485-487.

22. Lo YM, Tein MS, Lau TK, Haines CJ, Leung TN, Poon PM, et al. Quantitative analysis of fetal DNA in maternal plasma and serum: Implications for noninvasive prenatal diagnosis. Am J Hum Genet. 1998; 62: 768-775.

23. Lo YM. Fetal DNA in maternal plasma. Ann N Y Acad Sci. 2000; 906: 141-147.

24. Pertl B, Bianchi DW. Fetal DNA in maternal plasma: Emerging clinical applications. Obstet Gynecol. 2001; 98: 483-490.

25. Lo YM. Fetal DNA in maternal plasma: Progress through epigenetics. Ann N Y Acad Sci. 2006; 1075: 74-80.

26. Tong YK, Ding C, Chiu RW, Gerovassili A, Chim SS, Leung TY, et al. Noninvasive prenatal detection of fetal trisomy 18 by epigenetic allelic ratio analysis in maternal plasma: Theoretical and empirical considerations. Clin Chem. 2006; 52: 2194-2202.

27. Tsui NB, Chiu RW, Ding C, El-Sheikhah A, Leung TN, Lau TK, et al. Detection of trisomy 21 by quantitative mass spectrometric analysis of single-nucleotide polymorphisms. Clin Chem. 2005; 51: 2358-2362.

28. Li Y, Wenzel F, Holzgreve W, Hahn S. Genotyping fetal paternally inherited SNPs by MALDI-TOF MS using cell-free fetal DNA in maternal plasma: Influence of size fractionation. Electrophoresis. 2006; 27: 3889-3896. 
29. Gil MM, Accurti V, Santacruz B, Plana MN, Nicolaides KH. Analysis of cell-free DNA in maternal blood in screening for aneuploidies: Updated meta-analysis. Ultrasound Obstet Gynecol. 2017; 50: 302-314.

30. Verhoef TI, Hill M, Drury S, Mason S, Jenkins L, Morris S, et al. Non-invasive prenatal diagnosis (NIPD) for single gene disorders: Cost analysis of NIPD and invasive testing pathways. Prenat Diagn. 2016; 36: 636-642.

31. Graves CJ, Miller KE, Sellers AD. Maternal serum triple analyte screening in pregnancy. Am Fam Physician. 2002; 65: 915-921.

32. Brock DJ. Mechanisms by which amniotic-fluid alpha-fetoprotein may be increased in fetal abnormalities. Lancet. 1976; 2: 345-346.

33. Brock DJ, Sutcliffe RG. Alpha-fetoprotein in the antenatal diagnosis of anencephaly and spina bifida. Lancet. 1972; 2: 197-199.

34. Wald NJ, Cuckle H, Brock JH, Peto R, Polani PE, Woodford FP. Maternal serum-alpha-fetoprotein measurement in antenatal screening for anencephaly and spina bifida in early pregnancy. Report of U.K. collaborative study on alpha-fetoprotein in relation to neural-tube defects. Lancet. 1977; 1: 1323-1332.

35. Wang ZP, Li H, Hao LZ, Zhao ZT. The effectiveness of prenatal serum biomarker screening for neural tube defects in second trimester pregnant women: A meta-analysis. Prenat Diagn. 2009; 29: 960-965.

36. Palomaki GE, Hill LE, Knight GJ, Haddow JE, Carpenter M. Second-trimester maternal serum alpha-fetoprotein levels in pregnancies associated with gastroschisis and omphalocele. Obstet Gynecol. 1988; 71: 906-909.

37. Committee opinion No. 640: Cell-free DNA screening for fetal aneuploidy. Obstet Gynecol. 2015; 126: 691-692.

38. Roman AS, Gupta S, Fox NS, Saltzman D, Klauser CK, Rebarber A. Is MSAFP still a useful test for detecting open neural tube defects and ventral wall defects in the era of first-trimester and early second-trimester fetal anatomical ultrasounds? Fetal Diagn Ther. 2015; 37: 206-210.

39. Ultrasound in pregnancy [Internet]. Washington, DC: American College of Obstetricians and Gynecologists; 2016 [cited 2021 Apr 30]. Available from: https://www.acog.org/en/clinical/clinical-guidance/practice-

bulletin/articles/2016/12/ultrasound-in-pregnancy.

40. Norem CT, Schoen EJ, Walton DL, Krieger RC, O'Keefe J, To TT, et al. Routine ultrasonography compared with maternal serum alpha-fetoprotein for neural tube defect screening. Obstet Gynecol. 2005; 106: 747-752.

41. Fong KW, Toi A, Okun N, Al-Shami E, Menezes RJ. Retrospective review of diagnostic performance of intracranial translucency in detection of open spina bifida at the 11-13-week scan. Ultrasound Obstet Gynecol. 2011; 38: 630-634.

42. Chandra S, Scott H, Dodds L, Watts C, Blight C, Van Den Hof M. Unexplained elevated maternal serum alpha-fetoprotein and/or human chorionic gonadotropin and the risk of adverse outcomes. Am J Obstet Gynecol. 2003; 189: 775-781.

43. Dugoff L, Hobbins JC, Malone FD, Vidaver J, Sullivan L, Canick JA, et al. Quad screen as a predictor of adverse pregnancy outcome. Obstet Gynecol. 2005; 106: 260-267. 
44. Heazell AE, Hayes DJ, Whitworth M, Takwoingi Y, Bayliss SE, Davenport C. Biochemical tests of placental function versus ultrasound assessment of fetal size for stillbirth and small-forgestational-age infants. Cochrane Database Syst Rev. 2019; 5: CD012245.

45. Indications for outpatient antenatal fetal surveillance [Internet]. Washington, DC: American College of Obstetricians and Gynecologists; 2020 [cited 2021 Jun 3]. Available from: https://www.acog.org/en/clinical/clinical-guidance/committeeopinion/articles/2021/06/indications-for-outpatient-antenatal-fetal-surveillance.

46. Krause TG, Christens P, Wohlfahrt J, Lei U, Westergaard T, Nørgaard-Pedersen B, et al. Secondtrimester maternal serum alpha-fetoprotein and risk of adverse pregnancy outcome (1). Obstet Gynecol. 2001; 97: 277-282.

47. Gagnon A, Wilson RD, Society of Obstetricians and Gynaecologists of Canada Genetics Committee. Obstetrical complications associated with abnormal maternal serum markers analytes. J Obstet Gynaecol Can. 2008; 30: 918-932.

48. Keller NA, Rijshinghani A. Advantages of the Quadruple Screen over noninvasive prenatal testing. Clin Case Rep. 2016; 4: 244-246.

49. Scheffer PG, Wirjosoekarto SA, Becking EC, Weiss MM, Bax CJ, Oepkes D, et al. Association between low fetal fraction in cell-free DNA testing and adverse pregnancy outcome: $A$ systematic review. Prenat Diagn. 2021. doi: 10.1002/pd.6028.

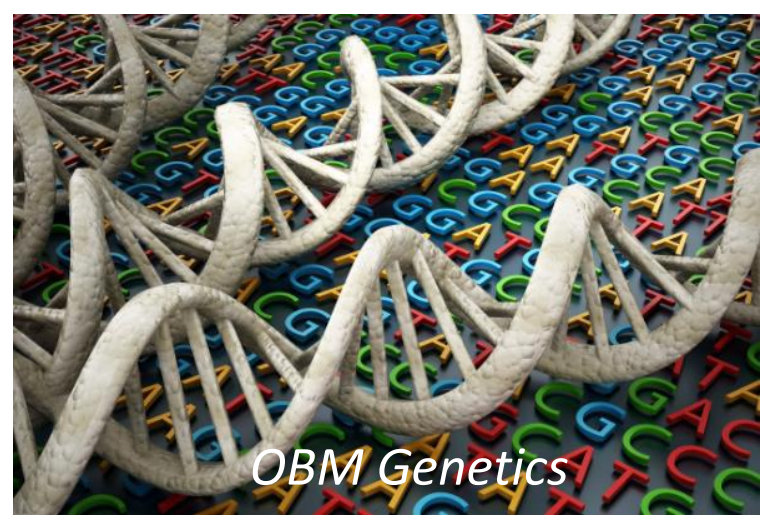

Enjoy OBM Genetics by:

1. Submitting a manuscript

2. Joining in volunteer reviewer bank

3. Joining Editorial Board

4. Guest editing a special issue

For more details, please visit:

http://www.lidsen.com/journals/genetics 